\title{
Hubungan Faktor-Faktor yang Mempengaruhi Kuat Tekan Beton
}

\author{
Rara Amelia, Suhendra*, Kiki Rizky Amalia \\ Program Studi Teknik Sipil Universitas Batanghari Jambi \\ *Correspondence email: Suhendra_domas@yahoo.com
}

\begin{abstract}
Abstrak. Penggunaan material sebagai bahan campuran beton dapat menjadi keuntungan dari perencanaan konstruksi, apabila komposisi campuran betonnya tepat. Kekuatan karakteristik beton menjadi perhatian penting bagi perencana dan pengendalian mutu, karena kekuatan beton biasanya memberikan gambaran kualitas beton secara keseluruhan. Kuat tekan beton dipengaruhi oleh banyak factor. Studi ini meneliti faktor yang mempengaruhi kuat tekan beton dari proporsi bahan-bahan penyusun beton saja.Adapun komponen-komponen yang mempengaruhi kuat tekan beton yang dikaji ialah Faktor Air-Semen, nilai abrasi, Faktor Agregat-Semen dan Faktor Luas Permukaan agregat. Kajian ini bertujuan untuk mengetahui hubungan pengaruh masing-masing komponen secara parsial dan kombinasi dua komponen atau lebih secara simultan terhadap kuat tekan beton dengan 15 hipotesis data yang ditelaah melalui program SPSS versi 22 dan Ms.Excel. Dari 100 data sekunder yang bersumber dari laporan perencanaan campuran beton pada Laboratorium Fakultas Teknik Universitas Batanghari diperoleh hasil Faktor Agregat-Semen memberikan pengaruh yang paling dominan secara parsial terhadap kuat tekan beton sebesar 63,8\%. Pada kombinasi 2 komponen yakni Faktor Agregat-Semen dan nilai abrasi secara simultan memberikan pengaruh yang paling dominan terhadap kuat tekan beton sebesar 65,7\%. Pada 3 kombinasi komponen yaitu Faktor Agregat-Semen, nilai abrasi dan Faktor Luas Permukaan secara simultan memberikan pengaruh yang paling dominan terhadap kuat tekan beton sebesar 71\%. Pengaruh 4 kombinasi komponen ialah Faktor Air-Semen, Faktor Agregat-Semen, nilai abrasi dan Faktor Luas Permukaan secara simultan memberikan pengaruh sebesar $70,7 \%$ terhadap kuat tekan beton.
\end{abstract}

Kata Kunci : beton, kuat tekan, hubungan faktor-faktor

\section{PENDAHULUAN}

Kuat tekan beton dipengaruhi banyak faktor, yaitu proporsi bahan-bahan penyusun, metode perancangan, perawatan beton, serta keadaaan pada saat pengecoran. Studi literatur ini hanya akan terfokus pada faktor yang mempengaruhi kuat tekan beton dari proporsi bahan-bahan penyusun beton saja.

Studi literatur ini dilakukan untuk menambah kajian mengenai hubungan pada setiap komponen bahan material penyusun beton yang mempengaruhi kuat tekan beton normal. Beton normal digunakan dalam penelitian ini karena sebagian besar uji campuran beton yang dilakukan di Laboratorium Fakultas Teknik Universitas Batanghari menggunakan beton jenis ini.

\section{Tujuan Penelitian}

1. Mengetahui pengaruh hubungan masing-masing komponen secara parsial terhadap kuat tekan benda uji beton yang berumur 7 hari.

2. Mengetahui pengaruh hubungan kombinasi 2 komponen antara FAS, nilai abrasi, FAgS dan FLP secara simultan terhadap kuat tekan benda uji beton normal.

3. Mengetahui pengaruh hubungan kombinasi 3 komponen antara FAS, nilai abrasi, FAgS dan FLP secara simultan terhadap kuat tekan benda uji beton normal.

4. Mengetahui pengaruh hubungan kombinasi 4 komponen antara FAS, nilai abrasi, FAgS dan FLP secara simultan terhadap kuat tekan benda uji beton normal.

\section{Kuat Tekan Beton}

Kuat tekan beton banyak dipengaruhi oleh beberapa faktor, parameter-parameter yang paling penting mempengaruhi kekuatan beton menurut Edward G. Nawy (2009) antara lain :

1. Kualitas semen

2. Proporsi semen terhadap campuran ialah Faktor Air Semen (FAS).

3. Kekuatan agregat ialah nilai abrasi dari agregat kasar dan luas permukaan agregat,

4. Interaksi atau adesi antara pasta semen dengan agregat berupa rasio agregat-semen.

Kekuatan beton sangat dipengaruhi oleh banyak faktor, ACI (American Concrete Institute) menjelaskan bahwa luas permukaan agregat adalah turunan dari beberapa faktor yang mempengaruhi workability beton.

Faktor Air-Semen 
Faktor Air-Semen adalah rasio berat air terhadap berat semen. Adapun hubungan antara Faktor Air/Semen terhadap kuat tekan beton ditunjukkan pada gambar 1 di bawah ini.

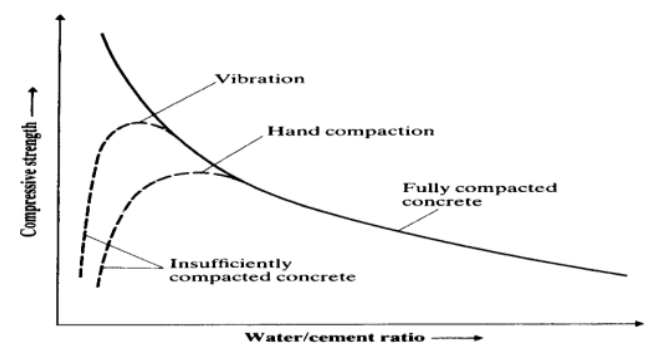

\section{Gambar 1 Hubungan Antara Faktor Air/Semen Terhadap Kuat Tekan (Sumber: A.M Neville, 2010).}

Semakin kecil nilai FAS yang dipakai maka akan menghasilkan kekuatan beton yang semakin baik pula. Campuran beton yang menggunakan nilai FAS yang besar, akan lebih sedikit membutuhkan pasta semen, sebaliknya campuran beton yang menggunakan nilai FAS kecil, akan lebih banyak membutuhkan pasta semen.

\section{Nilai Abrasi dari Agregat}

Pengaruh abrasi terhadap kuat tekan beton ini dapat digambarkan bahwa beton dengan kuat hancur yang besar juga mempunyai daya tahan terhadap kikisan yang besar. Apabila suatu agregat kasar dengan nilai abrasi yang kecil maka semakin besar kuat tekan yang dihasilkan, begitu pula sebaliknya (Yuni Damayanti,2015).

\section{Faktor Agregat-Semen}

Ketika nilai Faktor Agregat-Semen kecil maka rongga antar agregat terlapisi oleh pasta semen yang membuat beton mudah dicampur, sehingga kemampuan kerja beton meningkat. Hubungan Faktor Agregat-Semen terhadap kuat tekan beton ditunjukkan pada gambar 2 berikut.

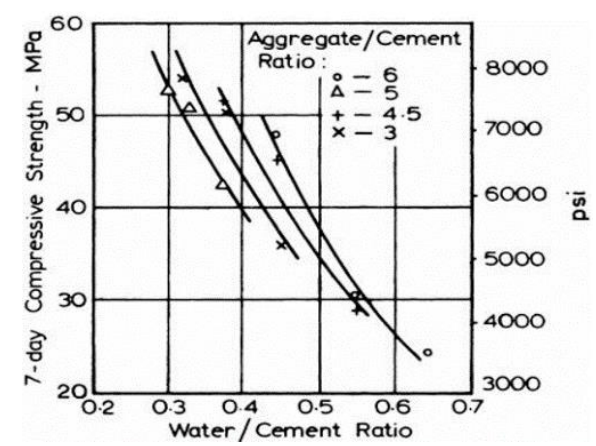

Gambar 2 Hubungan Rasio Agregat/Semen pada Kekuatan Beton

(Sumber : A.M Neville \& JJ.Brooks, 2010)

\section{Faktor Luas Permukaan}

ACI (American Concrete Institute) menjelaskan bahwa luas permukaan agregat adalah turunan dari beberapa faktor yang mempengaruhi workability beton yang mempengaruhi kuat tekan beton.

Tattersall (1991) menjelaskan bahwa luas spesifik permukaan agregat adalah rasio dari total luas permukaan terhadap total massa atau volume, dan diukur dalam $\mathrm{m}^{2} / \mathrm{kg}$. Nilai FLP untuk satu set ukuran saringan menurut TAI seperti pada tabel 1 di bawah ini.

Tabel 1 Faktor Luas Permukaan

\begin{tabular}{|c|c|c|}
\hline \multicolumn{2}{|c|}{ Saringan } & \multirow{2}{*}{$\begin{array}{c}\text { FLP } \\
\mathrm{m}^{2} / \mathrm{kg}\end{array}$} \\
\hline No & Bukaan, mm & \\
\hline$>$ No. 4 & $>4,75$ & 0,41 \\
\hline No. 8 & 2,36 & 0,82 \\
\hline No. 16 & 1,18 & 1,64 \\
\hline No. 30 & 0,6 & 2,87 \\
\hline No. 50 & 0,3 & 6,14 \\
\hline No. 100 & 0,15 & 12,29 \\
\hline No. 200 & 0,075 & 32,77 \\
\hline
\end{tabular}


Catatan : - Untuk semua ukuran saringan di atas No. 4 diperhitungkan sebagai $0,41 \mathrm{~m}^{2} / \mathrm{kg}$.

- FLP digunakan jika seluruh urutan saringan digunakan.

Pada penelitian dari Newman dan Teichenne (1954) membuktikan bahwa jika luas permukaan spesifik agregat dalam campuran beton bertambah tetapi Faktor Air Semen (FAS) masih sama, maka kuat tekan beton dan kelecakan akan berkurang.

\section{Aplikasi SPSS}

SPSS adalah akronim dari Statistical Package for Social Science,yaitu software untuk menganalisis data, melakukan perhitungan statistik baik untuk statistik parametrik maupun non-parametik dengan berbasis windows (Ghozali, 2016).

Uji normalitas dilakukan dengan menggunakan uji Kolmogorov Smirnov. Jika nilai signifikannya lebih besar dari 0,05 maka data distribusi tersebut dinyatakan normal.

Uji Multikolinieritas bertujuan untuk menguji apakah dalam model regresi ditemukan adanya korelasi antar komponen bebas (komponen X) atau tidak. Data yang baik seharusnya tidak terjadi korelasi di antara komponen bebas (komponen X). Pengambilan keputusan pada uji multikolinieritas ini adalah nilai tolerance $>0,10$ dengan nilai VIF < 10 (Ghozali, 2018).

Uji t dilakukan untuk mengetahui besarnya pengaruh masing-masing komponen independen yaitu komponen FAS, nilai abrasi, FAgS dan FLP secara individual (parsial) terhadap komponen dependen (kuat tekan beton).

Uji $\mathrm{f}$ atau disebut juga dengan Analisis Komponen (ANOVA) digunakan untuk menguji tingkat signifikansi pengaruh beberapa komponen independen secara bersama-sama terhadap komponen terikat, yaitu dengan tingkat signifikansi 0,05 .

Berdasarkan nilai signifikan level 0,05 ( $\alpha=0,05 \%)$ (Ghozali 2018). Dasar pengambilan keputusan uji f adalah :

1. Jika nilai sig < 0,05 maka Ha diterima dan Ho ditolak, artinya terdapat pengaruh signifikan komponen $\mathrm{X}$ secara simultan terhadap komponen Y.

2. Jika nilai sig > 0,05 maka Ha ditolak dan Ho diterima, artinya tidak terdapat pengaruh komponen $\mathrm{X}$ secara simultan terhadap komponen Y.

\section{METODE}

Sumber data yang digunakan dalam penelitian ini diperoleh dari laporan perencanaan campuran beton pada Laboratorium Fakultas Teknik Universitas Batanghari Jambi.

Metode analisis data yang digunakan pada penelitian ini adalah menggunakan aplikasi Ms.Excel dan SPSS. Aplikasi Ms.Excel digunakan untuk mengolah data sekunder, sedangkan SPSS digunakan untuk menganalisis data yang telah diolah.

Tahapan penelitian digambarkan melalui diagram alir (flowchart). Berikut di bawah ini disajikan gambar 3 bagan alir pada penelitian ini

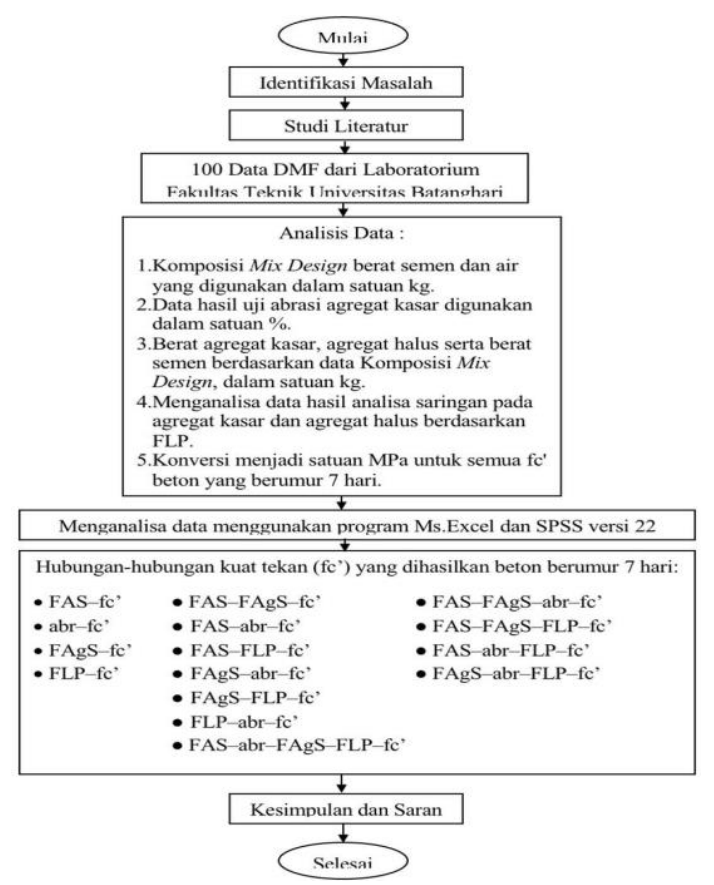

Gambar 3 Bagan Alir Penelitian 


\section{HASIL DAN PEMBAHASAN}

Data diperoleh dari laporan perencanaan campuran beton yang bersumber dari Laboratorium Teknik Universitas Batanghari. Adapun jumlah data yang diperoleh sebanyak 100 data pada tahun 2018, 2019 dan 2020. Karakteristik data dalam penelitian ini meliputi Faktor Air-Semen (FAS) dan Faktor Agregat-Semen (FAgS) yang diperoleh dari mix design beton, sedangkan nilai abrasi (abr) yang diperoleh dari hasil uji abrasi, dan Faktor Luas Permukaan (FLP) agregat diperoleh dari analisa saringan agregat kasar maupun agregat halus. Berikut adalah rekapitulasi olahan data DMF.

Tabel 2 Rekapitulasi Faktor-Faktor dan Kuat Tekan Beton

\begin{tabular}{|c|c|c|c|c|c|}
\hline No & FAS & FAgs & Abr & FLP & fc' \\
\hline 1 & 0,43 & 3,5 & 22,74 & 6,73 & 22 \\
\hline 2 & 0,45 & 4,1 & 22,74 & 6,73 & 20 \\
\hline 3 & 0,602 & 5 & 22,74 & 6,73 & 15 \\
\hline 4 & 0,47 & 4,3 & 22,7 & 4,85 & 18,45 \\
\hline 5 & 0,46 & 4,1 & 21,39 & 5,78 & 18 \\
\hline 6 & 0,49 & 4,4 & 21,39 & 5,78 & 18 \\
\hline 7 & 0,45 & 3,9 & 24,3 & 9,08 & 20 \\
\hline 8 & 0,45 & 3,9 & 24,28 & 6,19 & 18 \\
\hline 9 & 0,45 & 3,9 & 24,8 & 10,56 & 20 \\
\hline 10 & 0,48 & 3,8 & 24,7 & 6,65 & 18,3 \\
\hline 11 & 0,52 & 4,5 & 24,7 & 6,00 & 16 \\
\hline 12 & 0,42 & 3,6 & 25,64 & 8,09 & 18 \\
\hline 13 & 0,41 & 3,2 & 21,39 & 13,16 & 26 \\
\hline 14 & 0,475 & 3,9 & 26,5 & 8,34 & 18 \\
\hline 15 & 0,465 & 4,1 & 20,32 & 6,67 & 17 \\
\hline 16 & 0,41 & 3,2 & 21,39 & 5,95 & 26 \\
\hline 17 & 0,465 & 4,1 & 20,46 & 6,73 & 16 \\
\hline 18 & 0,45 & 3,9 & 24,12 & 6,17 & 18 \\
\hline 19 & 0,48 & 3,7 & 24,2 & 6,64 & 19,1 \\
\hline 20 & 0,599 & 4,4 & 26,8 & 4,71 & 12,1 \\
\hline 21 & 0,39 & 3,5 & 24,42 & 11,02 & 25,1 \\
\hline 22 & 0,45 & 3,9 & 18,9 & 7,60 & 19,8 \\
\hline 23 & 0,45 & 3,9 & 18,9 & 7,67 & 19,1 \\
\hline 24 & 0,451 & 4,2 & 22,5 & 4,99 & 18,2 \\
\hline 25 & 0,47 & 4,5 & 14,3 & 5,36 & 18 \\
\hline 26 & 0,483 & 4,1 & 24,38 & 8,09 & 18 \\
\hline 27 & 0,47 & 4,5 & 14,3 & 5,36 & 18 \\
\hline 28 & 0,46 & 4,1 & 21,39 & 5,78 & 18 \\
\hline 29 & 0,59 & 5,3 & 24,7 & 6,00 & 10,9 \\
\hline 30 & 0,59 & 5,3 & 24,7 & 6,00 & 10,9 \\
\hline 31 & 0,45 & 4,1 & 26,8 & 10,63 & 22,3 \\
\hline 32 & 0,519 & 4,5 & 33,7 & 7,31 & 19,3 \\
\hline 33 & 0,48 & 4,5 & 13,6 & 4,98 & 17,7 \\
\hline 34 & 0,509 & 4,9 & 32,89 & 6,97 & 14,2 \\
\hline 35 & 0,46 & 4,4 & 18,04 & 7,66 & 15,5 \\
\hline 36 & 0,46 & 4,4 & 18,04 & 7,66 & 15,3 \\
\hline 37 & 0,451 & 4,2 & 18,24 & 9,59 & 21,8 \\
\hline 38 & 0,42 & 3,5 & 24,7 & 9,59 & 21,4 \\
\hline 39 & 0,5 & 4,7 & 21,82 & 5,62 & 13,9 \\
\hline 40 & 0,501 & 4,8 & 13,06 & 9,59 & 14 \\
\hline 41 & 0,36 & 3,1 & 20,18 & 10,63 & 23,4 \\
\hline 42 & 0,639 & 6,2 & 13,6 & 4,98 & 10,5 \\
\hline 43 & 0,5 & 4,8 & 14,02 & 7,42 & 15,8 \\
\hline 44 & 0,48 & 4,6 & 14,02 & 7,42 & 18,3 \\
\hline 45 & 0,451 & 4,2 & 22,48 & 5,04 & 18 \\
\hline 46 & 0,4 & 3,8 & 18,66 & 7,28 & 20,4 \\
\hline 47 & 0,501 & 4,7 & 36,18 & 9,85 & 13,8 \\
\hline 48 & 0,47 & 4,4 & 18,76 & 9,89 & 18,4 \\
\hline 49 & 0,461 & 4,2 & 25,8 & 9,37 & 18,5 \\
\hline 50 & 0,422 & 3,9 & 23,5 & 10,94 & 18,3 \\
\hline 51 & 0,43 & 4 & 14,9 & 5,35 & 18,4 \\
\hline 52 & 0,599 & 5,5 & 25,64 & 4,72 & 11,8 \\
\hline
\end{tabular}




\begin{tabular}{|c|c|c|c|c|c|}
\hline 53 & 0,59 & 5,3 & 24,7 & 6,00 & 13,2 \\
\hline 54 & 0,485 & 4,3 & 25,64 & 4,72 & 15,6 \\
\hline 55 & 0,501 & 4,7 & 23,56 & 6,33 & 17,51 \\
\hline 56 & 0,521 & 5 & 24,19 & 7,79 & 12,62 \\
\hline 57 & 0,58 & 5,3 & 20,28 & 11,02 & 18 \\
\hline 58 & 0,462 & 4,2 & 20,28 & 11,02 & 18,1 \\
\hline 59 & 0,42 & 3,6 & 13,04 & 11,02 & 24,24 \\
\hline 60 & 0,426 & 4 & 25 & 4,83 & 18 \\
\hline 61 & 0,426 & 4 & 22,25 & 4,83 & 18,3 \\
\hline 62 & 0,481 & 4,6 & 25 & 4,83 & 13,9 \\
\hline 63 & 0,46 & 3,9 & 20,86 & 6,83 & 17,8 \\
\hline 64 & 0,481 & 4,6 & 22,25 & 4,83 & 14 \\
\hline 65 & 0,415 & 3,5 & 22,76 & 10,30 & 20,75 \\
\hline 66 & 0,425 & 3,9 & 24,28 & 9,90 & 18,18 \\
\hline 67 & 0,449 & 4,1 & 26,1 & 6,59 & 17,26 \\
\hline 68 & 0,471 & 4,4 & 14,2 & 10,64 & 20,09 \\
\hline 69 & 0,549 & 4,9 & 14,3 & 6,20 & 17,35 \\
\hline 70 & 0,551 & 5,3 & 14,2 & 6,59 & 16,19 \\
\hline 71 & 0,48 & 4,6 & 25,94 & 7,36 & 13,7 \\
\hline 72 & 0,481 & 4,5 & 23,56 & 6,33 & 19,42 \\
\hline 73 & 0,491 & 4,6 & 24,68 & 8,34 & 15,27 \\
\hline 74 & 0,451 & 4,2 & 22,2 & 5,00 & 18,26 \\
\hline 75 & 0,48 & 4,2 & 15,88 & 8,75 & 18,43 \\
\hline 76 & 0,45 & 4 & 23,38 & 5,88 & 16,1 \\
\hline 77 & 0,45 & 4 & 24,28 & 5,88 & 17,3 \\
\hline 78 & 0,539 & 4,7 & 36,18 & 10,63 & 18,43 \\
\hline 79 & 0,415 & 3,5 & 24,15 & 8,02 & 18 \\
\hline 80 & 0,42 & 3,3 & 19,7 & 6,74 & 22 \\
\hline 81 & 0,521 & 5 & 29,17 & 7,73 & 14,2 \\
\hline 82 & 0,501 & 4,7 & 22,9 & 7,45 & 13,9 \\
\hline 83 & 0,45 & 3,6 & 19,58 & 11,02 & 24,8 \\
\hline 84 & 0,4 & 3,1 & 19,58 & 11,02 & 25 \\
\hline 85 & 0,376 & 3,3 & 24 & 6,02 & 23,4 \\
\hline 86 & 0,581 & 4,9 & 19,58 & 6,29 & 18 \\
\hline 87 & 0,5 & 4,4 & 24,18 & 6,19 & 19 \\
\hline 88 & 0,5 & 3,9 & 24,1 & 6,26 & 19 \\
\hline 89 & 0,42 & 3,3 & 19,7 & 8,09 & 23 \\
\hline 90 & 0,42 & 3,6 & 24,88 & 6,74 & 18 \\
\hline 91 & 0,471 & 4,3 & 31 & 7,06 & 19 \\
\hline 92 & 0,461 & 4,3 & 27 & 6,94 & 19 \\
\hline 93 & 0,469 & 4 & 16,9 & 8,72 & 18,3 \\
\hline 94 & 0,401 & 3,7 & 13,48 & 9,05 & 24 \\
\hline 95 & 0,38 & 3,1 & 15,3 & 9,28 & 20 \\
\hline 96 & 0,601 & 5,6 & 36,52 & 4,46 & 8,4 \\
\hline 97 & 0,519 & 4,5 & 30,9 & 5,70 & 14 \\
\hline 98 & 0,55 & 5 & 20,4 & 9,25 & 19 \\
\hline 99 & 0,578 & 5,7 & 36,52 & 4,85 & 14,5 \\
\hline 100 & 0,368 & 3,3 & 25,3 & 9,52 & 23,3 \\
\hline
\end{tabular}

Pengujian menggunakan program SPSS yang dalam hal ini akan dilakukan sebanyak 15 kali uji berdasarkan hipotesis yang terdapat dalam penelitian ini yakni meliputi :

Tabel 3 Hipotesis Data

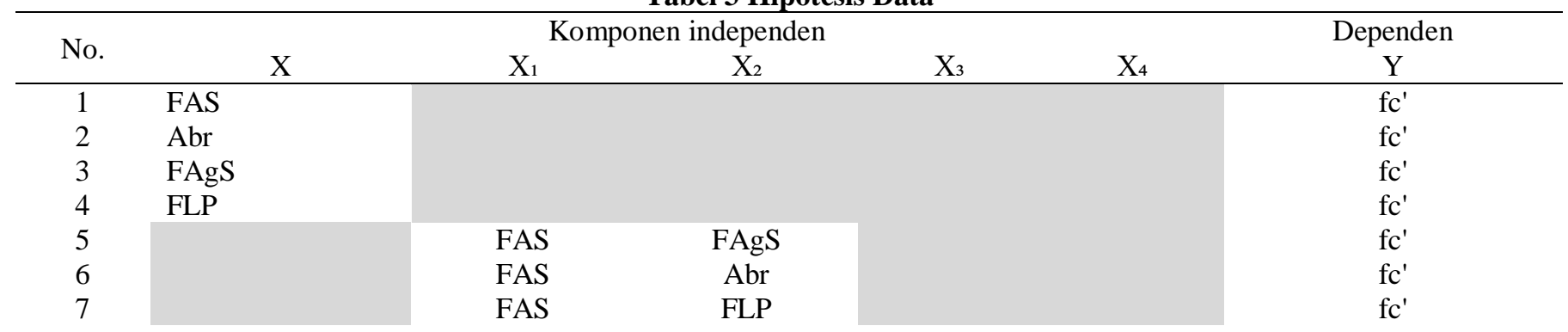




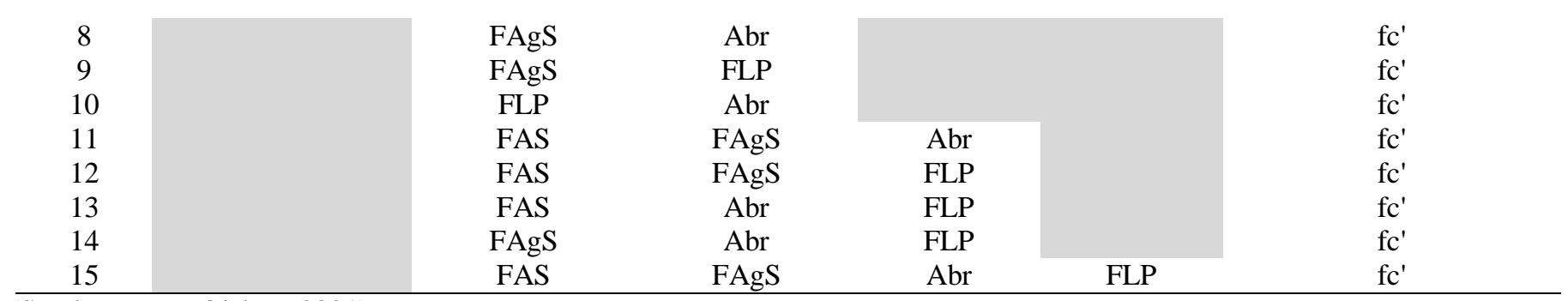

(Sumber : Data Olahan, 2021)

\section{Hubungan FAS Terhadap fc'}

Hasil uji normalitas menunjukkan bahwa data terdistribusi secara normal. Hasil uji t menunjukkan bahwa secara parsial terdapat pengaruh yang signifikan antara Faktor Air-Semen terhadap kuat tekan beton. Lebih lanjut, hasil uji koefisien determinasi menunjukkan bahwa pengaruh FAS terhadap fc' adalah sebesar 55,9\%. Berikut grafik hubungan Faktor Air-Semen terhadap kuat tekan beton berdasarkan hasil regresi Curve Estimation pada gambar di bawah ini.

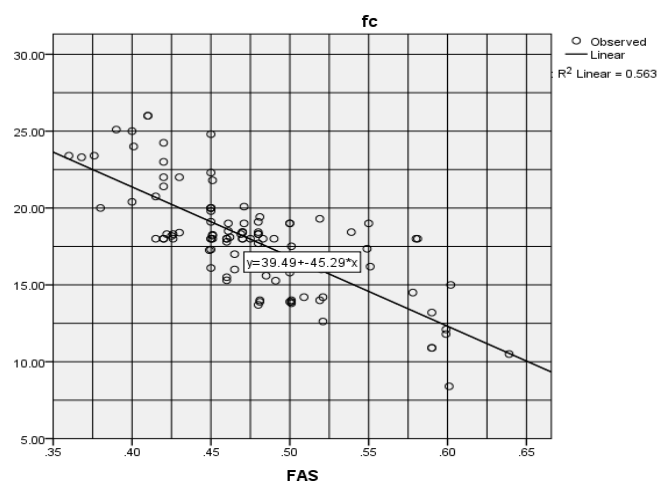

Gambar 4 Hubungan FAS dan fc'

Dari gambar yang disajikan dapat disimpulkan bahwa semakin besar nilai rasio air-semen maka kuat tekan beton semakin rendah.

\section{Hubungan Nilai Abrasi Terhadap fc'}

Hasil uji normalitas menunjukkan bahwa data terdistribusi tidak normal. Hasil uji t menunjukkan bahwa secara parsial terdapat pengaruh yang signifikan antara nilai abrasi terhadap kuat tekan beton. Lebih lanjut, hasil uji koefisien determinasi menunjukkan bahwa pengaruh nilai abrasi terhadap kuat tekan hanya sebesar 6,2\%. Dapat disimpulkan bahwa pada nilai abrasi ini tidak terlalu berpengaruh yang signifikan terhadap kuat tekan beton dibuktikan dengan kecilnya nilai $\mathrm{R}^{2}$. Berikut disajikan grafik hubungan nilai abrasi terhadap kuat tekan beton berdasarkan hasil regresi Curve Estimation.

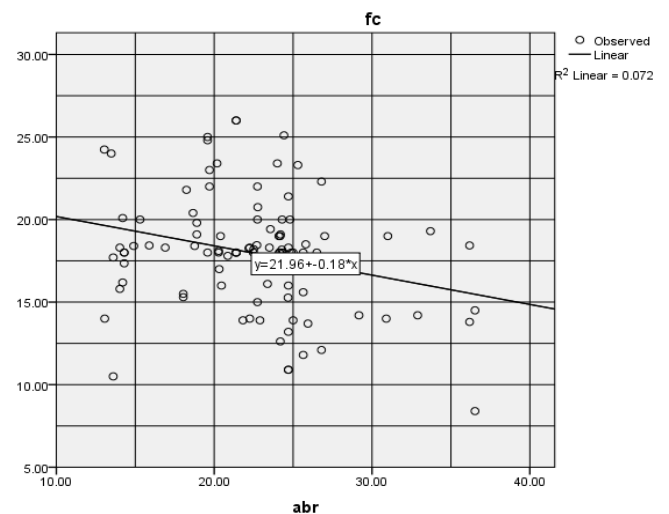

Gambar 5 Hubungan abr dan fc'

Berdasarkan grafik di atas terlihat bahwa data menunjukan beberapa nilai abrasi yang rendah tetapi kuat tekan betonnya tinggi, ada pula nilai abrasi yang rendah tetapi kuat tekan betonnya rendah pula 


\section{Hubungan FAgS Terhadap fe'}

Hasil uji normalitas menunjukkan bahwa data terdistribusi normal. Hasil uji t menunjukkan bahwa secara parsial terdapat pengaruh yang signifikan antara Faktor Agregat-Semen terhadap kuat tekan beton. Lebih lanjut, hasil uji koefisien determinasi menunjukkan bahwa pengaruh Faktor Agregat-Semen terhadap kuat tekan adalah sebesar $63,8 \%$. Berikut disajikan grafik hubungan nilai abrasi terhadap kuat tekan beton berdasarkan hasil regresi Curve Estimation.

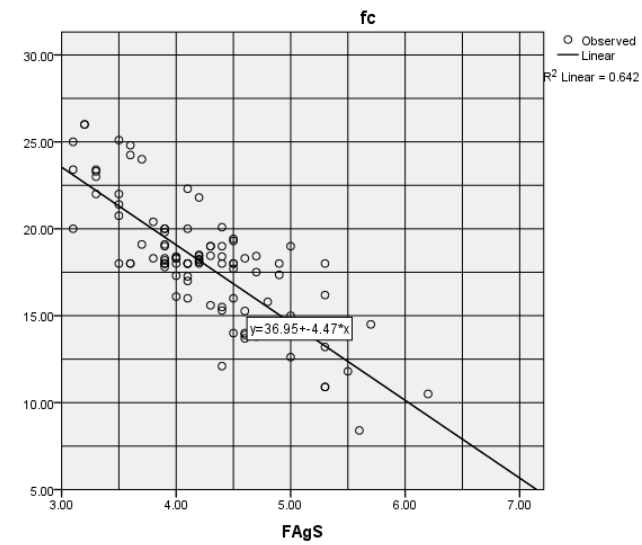

\section{Gambar 6 Hubungan FAgS dan fc'}

Dari grafik yang disajikan di atas terlihat bahwa kuat tekan beton mengalami penurunan seiring dengan meningkatnya Faktor Agregat-Semen.

\section{Hubungan FLP Terhadap fe'}

Hasil uji normalitas menunjukkan bahwa data terdistribusi secara normal. Hasil uji t menunjukkan secara parsial terdapat pengaruh yang signifikan antara Faktor Luas Permukaan terhadap kuat tekan beton. Lebih lanjut, hasil uji koefisien determinasi menunjukkan bahwa pengaruh Faktor Luas Permukaan terhadap kuat tekan adalah sebesar 26,6\%. Berikut di bawah ini disajikan grafik hubungan Faktor Luas Permukaan terhadap kuat tekan beton berdasarkan hasil regresi Curve Estimation.

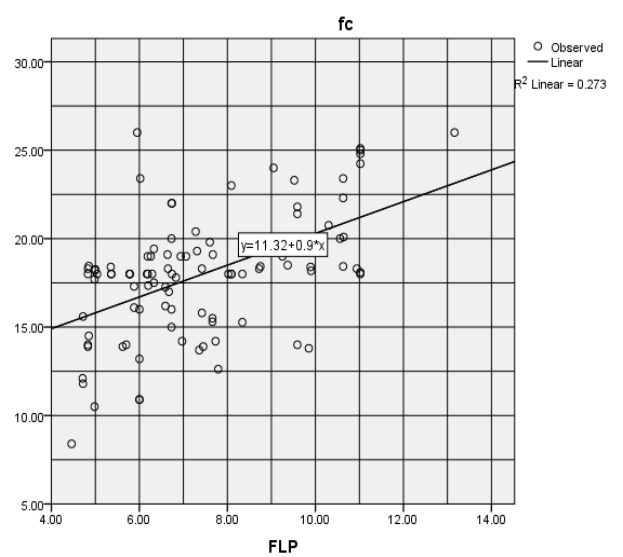

\section{Gambar 7 Hubungan FLP terhadap fc'}

Berdasarkan grafik di atas terlihat bahwa semakin besar nilai Faktor Luas Permukaan agregat maka semakin besar pula kuat tekan yang dihasilkan. Namun, jika dibandingkan dengan penelitian terdahulu (Newman, 1954) akan berbeda hasilnya yang menunjukkan bahwa jika permukaan agregat bertambah maka kuat tekan beton berkurang.

\section{Hubungan FAS dan FAgS Terhadap fc'}

Hasil uji normalitas menunjukkan bahwa data terdistribusi secara normal. Uji multikolonieritas menunjukkan bahwa tidak adanya interkorelasi antara FAS dan FAgS. Hasil uji F menunjukkan bahwa terdapat pengaruh yang signifikan antara FAS dan FAgS secara simultan terhadap $\mathrm{fc}^{\prime}$. Lebih lanjut, hasil uji koefisien determinasi menunjukkan bahwa pengaruh FAS dan FAgS terhadap fc' adalah sebesar 63,8\%. Di bawah ini grafik hubungan Faktor Air-Semen dan Faktor Agregat-Semen terhadap kuat tekan beton. 


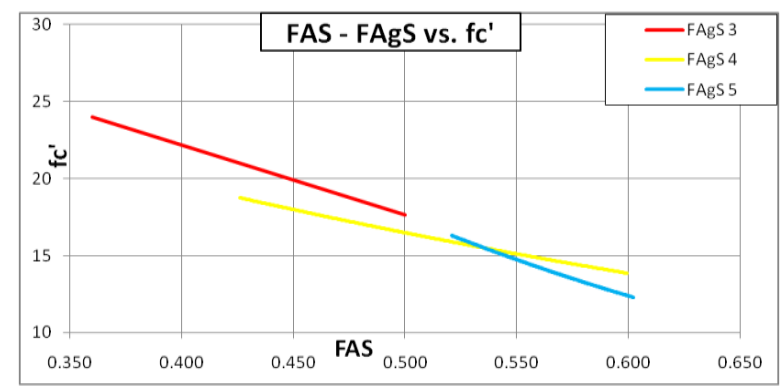

Gambar 8 Hubungan FAS-FAgS dan fc'

Berdasarkan grafik di atas, pada kasus Faktor Agregat-Semen yang bernilai 3, 4 juga 5 mengalami penurunan kuat tekan seiring meningkatnya Faktor Air-Semen.

\section{Hubungan FAS dan abr Terhadap fe'}

Hasil uji normalitas menunjukkan bahwa data terdistribusi secara normal. Uji multikolonieritas menunjukkan bahwa tidak adanya interkorelasi antara FAS dan nilai abrasi. Hasil uji F menunjukkan bahwa terdapat pengaruh yang signifikan antara FAS dan nilai abrasi secara simultan terhadap fc'. Lebih lanjut, hasil uji koefisien determinasi menunjukkan bahwa pengaruh FAS dan nilai abrasi terhadap fc' adalah sebesar 56,7\%. Di bawah ini disajikan grafik hubungan Faktor Air-Semen dan nilai abrasi terhadap kuat tekan beton.

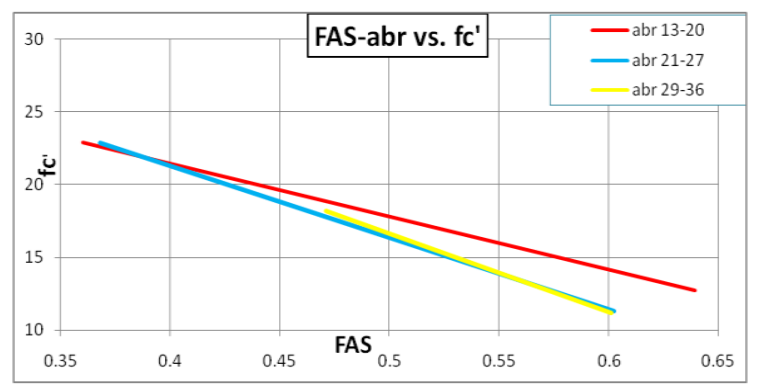

Gambar 9 Hubungan FAS-abr dan fc'

Dari data yang telah diolah terlihat bahwa semakin besar nilai abrasi diikuti dengan semakin besarnya Faktor Air-Semen maka kuat tekannya semakin kecil.

\section{Hubungan FAS dan FLP Terhadap fc'}

Hasil uji normalitas menunjukkan bahwa data terdistribusi secara normal. Uji multikolonieritas menunjukkan bahwa tidak adanya interkorelasi antara FAS dan FLP. Hasil uji F menunjukkan bahwa terdapat pengaruh yang signifikan antara FAS dan FLP secara simultan terhadap fc'. Lebih lanjut, hasil uji koefisien determinasi menunjukkan bahwa pengaruh secara simultan FAS dan FLP terhadap fc' adalah sebesar 63\%. Di bawah ini disajikan grafik hubungan Faktor Air-Semen dan Faktor Luas Permukaan terhadap kuat tekan beton.

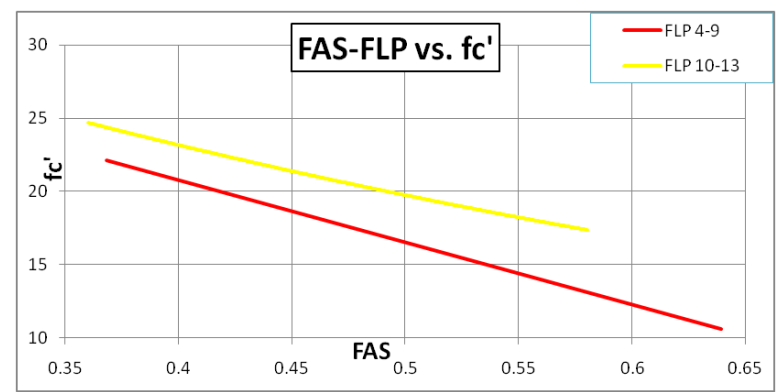

Gambar 10 Hubungan FAS-FLP dan fc'

Berdasarkan grafik di atas dapat disimpulkan bahwa semakin besar nilai Faktor Luas Permukaan maka semakin kecil nilai Faktor Air-Semennya diikuti dengan kecilnya nilai kuat tekan. 


\section{Hubungan FAgS dan abr Terhadap fc'}

Hasil uji normalitas menunjukkan bahwa data terdistribusi secara normal. Uji multikolonieritas menunjukkan bahwa tidak adanya interkorelasi antara FAgS dan nilai abrasi. Hasil uji $\mathrm{F}$ menunjukkan bahwa terdapat pengaruh yang signifikan antara FAgS dan nilai abrasi secara simultan terhadap fc'. Lebih lanjut, hasil uji koefisien determinasi menunjukkan bahwa pengaruh secara simultan FAgS dan nilai abrasi terhadap $\mathrm{fc}^{\prime}$ adalah sebesar 65,7\%. Berikut disajikan grafik hubungan Faktor Agregat-Semen dan nilai abrasi terhadap kuat tekan beton.

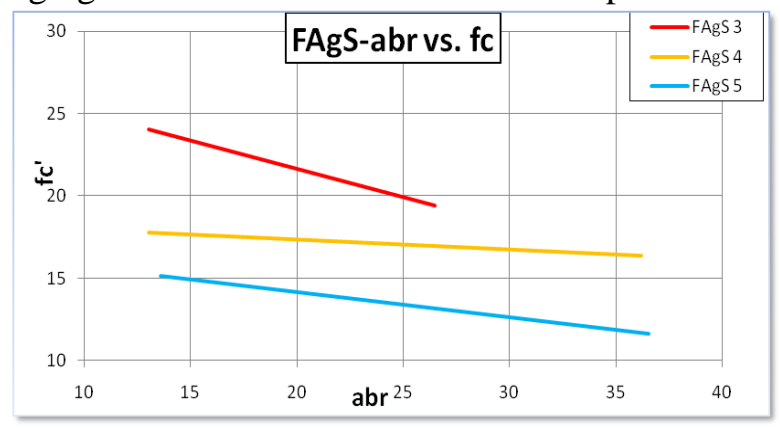

Gambar 11 Hubungan FAgS-abr dan fe'

Jika grafik dilihat secara keseluruhan didapat kesimpulan bahwa semakin besar nilai Faktor Agregat-Semen diikuti dengan besarnya nilai abrasi yang berpengaruh terhadap penurunan kuat tekan beton.

\section{Hubungan FAgS dan FLP Terhadap fe'}

Hasil uji normalitas menunjukkan bahwa data terdistribusi secara normal. Uji multikolonieritas menunjukkan bahwa tidak adanya interkorelasi antara FAgS dan FLP. Hasil uji F menunjukkan bahwa terdapat pengaruh yang signifikan antara FAgS dan FLP secara simultan terhadap fc'. Lebih lanjut, hasil uji koefisien determinasi menunjukkan bahwa pengaruh secara simultan FAgS dan FLP terhadap fc' adalah sebesar 64,4\%. Berikut disajikan grafik hubungan Faktor Agregat-Semen dan Faktor Luas Permukaan terhadap kuat tekan beton.

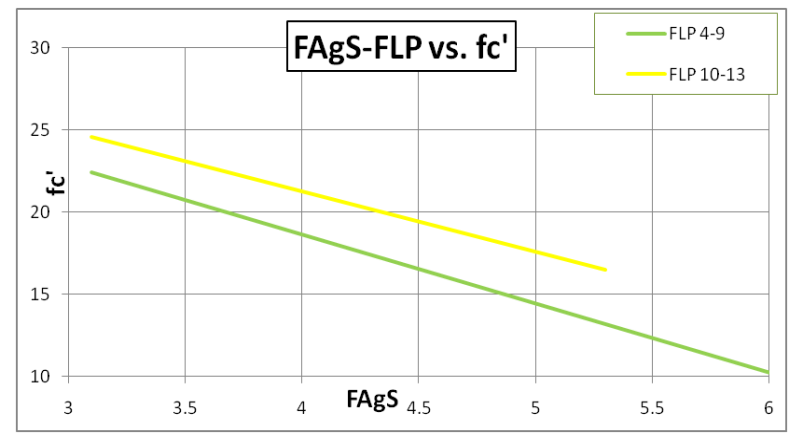

Gambar 12 Hubungan FAgS-FLP dan fc'

Dari grafik di atas terlihat bahwa semakin besar nilai FLP maka semakin kecil pula nilai FAgS, yang berpengaruh terjadinya kenaikan pada kuat tekan beton.

\section{Hubungan FLP dan abr Terhadap fe'}

Hasil uji normalitas menunjukkan bahwa data terdistribusi secara normal. Uji multikolonieritas menunjukkan bahwa tidak adanya interkorelasi antara FLP dan nilai abrasi. Hasil uji F menunjukkan bahwa terdapat pengaruh yang signifikan antara FLP dan nilai abrasi secara simultan terhadap fc'. Lebih lanjut, hasil uji koefisien determinasi menunjukkan bahwa pengaruh secara simultan FLP dan nilai abrasi terhadap fc' adalah sebesar 30,5\%.

Berikut disajikan grafik hubungan Faktor Luas Permukaan dan nilai abrasi terhadap kuat tekan beton. 


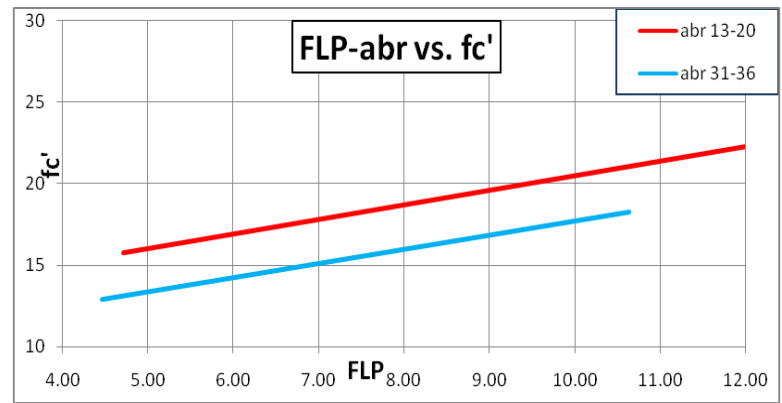

Gambar 13 Hubungan FLP-abr dan fc'

Berdasarkan grafik di atas terlihat bahwa semakin besar nilai abrasinya, maka semakin kecil nilai Faktor Luas Permukaan agregatnya yang berpengaruh pada penurunan kuat tekan beton yang dihasilkan.

\section{Hubungan FAS, FAgS, dan abr Terhadap fe'}

Hasil uji normalitas menunjukkan bahwa data terdistribusi secara normal. Uji multikolonieritas menunjukkan bahwa tidak adanya interkorelasi antara FAS, FAgS dan nilai abrasi. Hasil uji F menunjukkan bahwa terdapat pengaruh yang signifikan antara FAS, FAgS dan nilai abrasi secara simultan terhadap fc'. Lebih lanjut, hasil uji koefisien determinasi menunjukkan bahwa pengaruh secara simultan FAS, FAgS dan nilai abrasi terhadap fc' adalah sebesar $65,4 \%$.

\section{Hubungan FAS, FAgS, FLP Terhadap fe'}

Hasil uji normalitas menunjukkan bahwa data terdistribusi secara normal. Uji multikolonieritas menunjukkan bahwa tidak adanya interkorelasi antara FAS, FAgS dan FLP. Hasil uji F menunjukkan bahwa terdapat pengaruh yang signifikan antara FAS, FAgS dan FLP secara simultan terhadap fc'. Lebih lanjut, hasil uji koefisien determinasi menunjukkan bahwa pengaruh FAS, FAgS dan FLP secara simultan terhadap fc' adalah sebesar 69,3\%.

\section{Hubungan FAS, Nilai Abrasi, dan FLP Terhadap fe'}

Hasil uji normalitas menunjukkan bahwa data terdistribusi secara normal. Uji multikolonieritas menunjukkan bahwa tidak adanya interkorelasi antara FAS, nilai abrasi dan FLP. Hasil uji F menunjukkan bahwa terdapat pengaruh yang signifikan antara FAS, nilai abrasi dan FLP secara simultan terhadap fc'. Lebih lanjut, hasil uji koefisien determinasi menunjukkan bahwa pengaruh FAS, nilai abrasi dan FLP secara simultan terhadap fc' adalah sebesar $63,7 \%$.

\section{Hubungan FAgS, abr, dan FLP Terhadap fe'}

Hasil uji normalitas menunjukkan bahwa data terdistribusi secara normal. Uji multikolonieritas menunjukkan bahwa tidak adanya interkorelasi antara FAgS, nilai abrasi dan FLP. Hasil uji F menunjukkan bahwa terdapat pengaruh yang signifikan antara FAgS, nilai abrasi dan FLP secara simultan terhadap fc'. Lebih lanjut, hasil uji koefisien determinasi menunjukkan bahwa pengaruh FAgS, nilai abrasi dan FLP secara simultan terhadap fc' adalah sebesar $71 \%$.

\section{Hubungan FAS, FAgS, abr, dan FLP Terhadap fc'}

Hasil uji normalitas menunjukkan bahwa data terdistribusi secara normal. Uji multikolonieritas menunjukkan bahwa tidak adanya interkorelasi antara FAS, FAgS, nilai abrasi dan FLP. Hasil uji F menunjukkan bahwa terdapat pengaruh yang signifikan antara FAS, FAgS, nilai abrasi dan FLP secara simultan terhadap fc'. Lebih lanjut, hasil uji koefisien determinasi menunjukkan bahwa pengaruh FAS, FAgS, nilai abrasi dan FLP secara simultan terhadap fc' adalah sebesar $70,7 \%$.

\section{SIMPULAN}

1. Faktor Agregat-Semen memberikan pengaruh yang paling dominan secara parsial terhadap kuat tekan beton sebesar 63,8\%.

2. Pada kombinasi 2 komponen yakni Faktor Agregat-Semen dan nilai abrasi secara simultan memberikan pengaruh yang paling dominan terhadap kuat tekan beton sebesar $65,7 \%$.

3. Pada 3 kombinasi komponen yaitu Faktor Agregat-Semen, nilai abrasi dan Faktor Luas Permukaan secara simultan memberikan pengaruh yang paling dominan terhadap kuat tekan beton sebesar $71 \%$.

4. Pengaruh 4 kombinasi komponen ialah Faktor Air-Semen, Faktor Agregat-Semen, nilai abrasi dan Faktor Luas Permukaan secara simultan memberikan pengaruh sebesar 70,7\% terhadap kuat tekan beton. 


\section{Saran}

Menyadari keterbatasan pengetahuan maupun kemampuan penulis pada penelitian ini, berikut beberapa saran untuk dapat dilanjutkan oleh peneliti lain :

1. Penelitian ini dapat dilanjutkan dengan membuat grafik sistem nomogram yakni mengkombinasi 4 komponen yang meliputi Faktor Air-Semen, nilai abrasi, Faktor Agregat-Semen, dan Faktor Luas Permukaan agregat menggunakan program-program software yang mendukung.

2. Penelitian ini dapat dilanjutkan dengan menganalisa hubungan faktor-faktor yang mempengaruhi kuat tekan beton lainnya seperti pemadatan beton, perawatan beton, dan lain sebagainya.

\section{DAFTAR PUSTAKA}

Darwis Fitro, Sultan Amir Mufti, dan Anwar Chairul. (2016).Pengaruh Variasi Faktor Air Semen Terhadap Kuat Tekan Beton Beragregat Batu Apung.

Ginting, Arusmalem. (2012). Pengaruh Rasio Agregat Semen dan Faktor Air Semen Terhadap Kuat Tekan dan Porositas Beton.

IBM SPSS Statistics Versi 22

Neville, A. B. (1987). Concrete Technology : Longman Group ltd. London.

Neville, A. (2011). Properties Of Concrete 5th Edition.

SNI 03-2843-2000. Tata cara pembuatan rencana campuran.

SNI 03-2847-2002. Tata Cara Perencanaan Struktur Beton Untuk Bangunan Gedung.

Tattersall, G. (1991).Workability and Quality Control of Concrete. London, Britania Raya: E\&FN Spon.

Yuni, Damayanti. (2015). Hubungan Nilai Abrasi Agregat Kasar Terhadap Kuat Tekan Beton. 